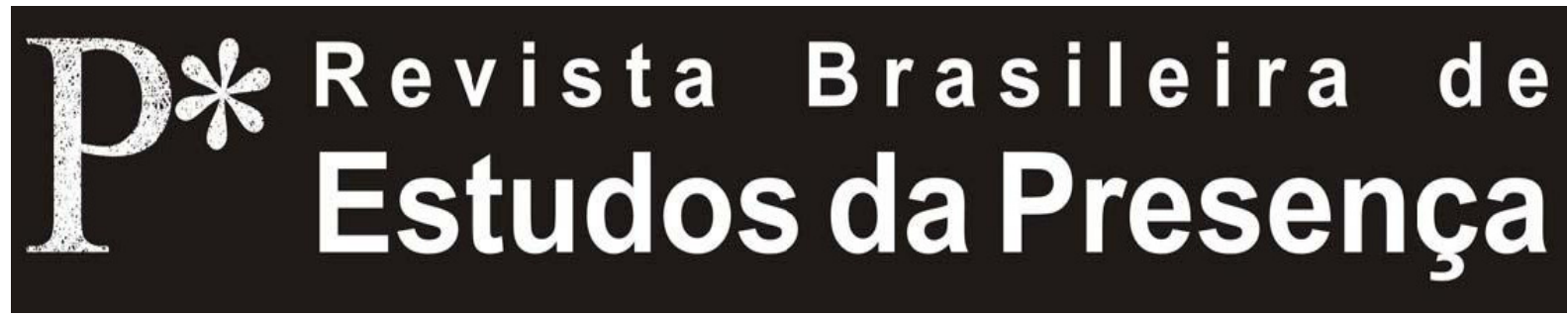

DOI - http://dx.doi.org/10.1590/2237-266039227

ISSN 2237-2660

\title{
La Presencia de los Legados en Performances Argentinas Contemporáneas
}

\author{
Federico Baeza \\ Instituto Universitario Nacional del Arte - IUNA, Buenos Aires, Argentina
}

\begin{abstract}
RESUMEN - La Presencia de los Legados en Performances Argentinas Contemporáneas - En torno al espacio interdisciplinario de la performance, diversas producciones argentinas de la última década tienen el objetivo de reflexionar sobre la transmisión de los legados generacionales que circulan en la vida cotidiana. Nos centraremos en ciertas obras de Verónica Gómez que documentan y analizan objetos domésticos heredados, luego observaremos la producción de Gabriel Baggio que indaga en los fenómenos semióticos presentes en la transmisión de imágenes y prácticas, finalmente nos focalizaremos en proyectos de Ana Gallardo donde se tematizan narrativas recurrentes alrededor de los recuerdos y los sentimientos.
\end{abstract}

Palabras-clave: Performance. Argentina. Transmisión Generacional. Vida Cotidiana. Arte Contemporáneo.

ABSTRACT - The Presence of Legacies in Contemporary Argentine Performances Concerning the interdisciplinary space of performance, several Argentine productions of the last decade aim to reflect on the transmission of generational legacies that circulate in daily life. We will focus on Verónica Gómez's works that document and analyze domestic inherited objects, then we will ponder over Gabriel Baggio's production that investigates semiotic phenomena present in the transmission of images and practices, finally, we will focus on Ana Gallardo's projects that have as themes constant narratives about memories and feelings.

Keywords: Performance. Argentina. Generational Transmission. Daily Life. Contemporary Art.

RÉSUMÉ - La Présence d'Héritages dans la Performance Contemporaine Argentine - Dans l'espace interdisciplinaire de la performance, diverses productions argentines de la dernière décennie ont pour objectif de réfléchir sur la transmission des héritages générationnels qui circulent dans la vie quotidienne. Cet article se penchera tout d'abord sur certaines œuvres de Verónica Gómez qui inventorient et analysent des objets domestiques légués. Il sera question ensuite d'observer la production de Gabriel Baggio qui s'interroge sur les phénomènes sémiotiques présents dans la transmission d'images et de pratiques et, enfin, sur les projets d'Ana Gallardo dont la thématique est celle des récits récurrents autour des souvenirs et des sentiments.

Mots-clés: Performance. Argentine. Transmission Générationnelle. Vie Quotidienne. Art Contemporain. 
La vida cotidiana parece ser un escenario marcado por la cercanía, por un ambiente inmediato, un mundo concreto, donde se reproduce la sociedad en cada uno de sus estratos particulares mediante la transmisión oral que asegura la continuidad de una serie de objetos, prácticas y saberes. En esta perspectiva, inaugurada por Agnès Heller (1998), la vida cotidiana se constituye como un espacio donde transitan una serie de legados que dependen de actos de objetivación donde lo dado por las generaciones precedentes es reinterpretado en la misma acción de comunicar estas herencias a lo descendientes. Este carácter reproductivo del ámbito cotidiano lo define como un espacio liminal entre el sostenimiento biológico de la especie y la (re)creación de la cultura. Las interacciones que aseguran dichas transmisiones se dan en una comunicación cara a cara, en el habla cotidiana, reino de la palabra oral que resistiría el progreso de los diversos dispositivos comunicacionales marcados por el contacto diferido (desde la escritura a los medios de comunicación masivos). El avance de la sociedad del espectáculo, según Guy Debord (2008), interpone la distancia y la pasividad de la representación en el seno de estas proximidades cotidianas marcadas por vínculos personales directos, en dicho sentido su vaticinio es lapidario: "[...] la conversación está casi muerta, y pronto estarán muertos muchos de los que sabían hablar" (Debord, 2003, p. 41).

La indagación de este mundo inmediato de la cotidianidad definido por la charla, el diálogo y los intercambios entre sujetos inmersos en escenas de cercanía es uno de los rasgos de época que caracterizan nuestra actualidad. En este sentido, Leonor Arfuch (2010) señala la continua expansión del espacio biográfico contemporáneo en el horizonte de los medios de comunicación así como en el territorio de las prácticas artísticas. Este movimiento incluye la proliferación de biografías literarias e históricas, libros de memorias, epistolarios, diarios íntimos, crónicas de viaje, proyectos audiovisuales y escénicos con acento autobiográfico, la producción periodística en torno a géneros como el perfil, la entrevista, las declaraciones confesionales, pasando por las diversas formas del reality televisivo hasta las narraciones alrededor de las vivencias en los discursos académicos de las ciencias sociales. En estos ámbitos puede observarse la recurrencia a la experiencia en primera persona en la construcción de relatos de vida, ya sea propia o ajena, ya sea privilegiando su valor testimonial o interpelando sus capacidades ficcionales. Este panorama también 
puede completarse con las diversas estrategias de exhibición del yo en las redes sociales lo que, según Paula Sibilia (2008), instituye a la intimidad contemporánea como espectáculo. En el ámbito específicamente teatral argentino este fenómeno ya fue analizado por Beatriz Trastoy (2002) en la escena de los 1980 y 1990, donde el unipersonal retoma las estrategias de la autoficción, la narración testimonial, el autorretrato, la memoria y el relato de viajes.

La perspectiva de Arfuch reelabora las relaciones entre géneros primarios y secundarios tal como los definiera Mijaíl Bajtín (2005). En la actualidad el espacio biográfico problematizaría los lugares estables de los géneros primarios o simples (instancias de la comunicación cotidiana mayormente oral como la anécdota, el chiste o la conversación) y de los secundarios o complejos (discursos más organizados que pueden tener procedencias mediáticas, literarias, artísticas o políticas, entre otros tipos marcados generalmente por procesos de escritura) que se hacen más inasibles y porosos. En la mirada bajtiniana, los géneros secundarios son los que mayormente reinterpretan y descontextualizan a los primarios, ejemplos típicos son los casos de la imitación del diálogo cotidiano en el teatro naturalista o la inclusión de la carta en la novela decimonónica. Estos géneros marcados por procesos de escritura reelaborarían a los géneros simples que tendrían un contacto más directo con la esfera de la vida diaria.

En contraposición, hoy es posible pensar la hibridez contemporánea de los géneros en, al menos, dos sentidos. Por un lado, reparando en las huellas de los discursos mediáticos en nuestras maneras de decir en la vida de todos los días como un factor que contamina la pureza de los géneros primarios. Por otro lado, los géneros secundarios, focalizando en los discursos artísticos que son de nuestro particular interés, también asumen lógicas procedentes de los géneros simples, un ejemplo interesante puede encontrarse en los proyectos artísticos contemporáneos analizados por Grant Kester (2004). En estas iniciativas, definidas como un nuevo género de arte público, se intenta construir plataformas de conversación e intercambio de puntos de vista entre diversos actores sociales, eliminando la mediación de un texto u obra clausurada para instituir estos procesos de interacción como la misma experiencia artística.

En este horizonte se sitúa la producción artística que analizaremos. Estos proyectos indagan en ese espacio inmediato y próximo que configura la vida cotidiana, exploran el potencial estético de 
biografías concretas, pero no intentan reparar en el carácter excepcional de dichas experiencias, tampoco dan cuenta de un espacio íntimo que se cierra, un hortus conclusus donde hacer crecer una personalidad individual y autosuficiente. Sus investigaciones se centran en ese sustrato compartido, en la proliferación de las artes del hacer según las palabras de Michel De Certeau (2006). Se trata de un territorio en común que es un espacio fértil para la representación, la puesta en escena, la ficción y el detenimiento contemplativo. Donde los recuerdos pueden museificarse, las herencias reinterpretarse, las narraciones constituirse como puestas en escena de la propia existencia, donde la reproducción de la vida cotidiana también da lugar a la transformación, la invención y el olvido.

\section{Verónica Gómez: analizar los recuerdos, intuir las ausencias, intercambiar experiencias}

El proyecto Casa Museo, que se extiende entre los años 2003 y 2005, tiene su epicentro en la casa de los abuelos paternos de Verónica Gómez, situada en Caseros, al oeste del Gran Buenos Aires, donde entonces ella vivía. Podríamos decir que su lógica responde a la problemática del site-specific que busca interpelar la mecánica de un espacio doméstico concreto alejado de los circuitos artísticos. La experiencia se inicia con el descubrimiento de la habitación de huéspedes; sus primeros pasos se dirigen a la exploración de las reliquias familiares que se encuentran en este cuarto situado en un segundo piso deshabitado. Así recuerda la artista su encuentro con estos objetos:

Eran cosas que me llevaban a la historia familiar vía paterna, como la inmigración, mis abuelos eran españoles. Había un cúmulo de información y de documentos que también eran afectivos, entonces yo sabía que estaba en ese lugar absorbiendo eso, después hacia donde iba eso, en ese momento no lo sabía. Me trazaba pequeñas metas, pequeños puertos digamos, empecé a pensar líneas para bordar esos objetos, una fue dibujarlos, otra fue hacer unos frottages con grafito, otra fue juntar muestras de la habitación ${ }^{1}$.

Mediante el dibujo, el frottage y diversos procedimientos de extracción de muestras ${ }^{2}$ puestos en escena con humor e ironía, Verónica desarrolló operaciones indiciarias que le permiten generar vestigios, seleccionar fragmentos de aquellos recuerdos familiares bajo la lógica de la impronta, el calco y la huella. Así es posible convocar su presencia y detenerse frente a ellos, contemplarlos, generando diversas instancias de documentación que constituían una trama de 
registros, maneras de traducir dichos objetos del recuerdo. Este efecto de catalogación y generación de un archivo, tomado como finalidad en sí misma en Casa Museo, también convoca la idea del museo determinado por una valoración no-utilitaria, descontextualizadora y aurática de los objetos junto a una voluntad analítica explicitada en el montaje expositivo.

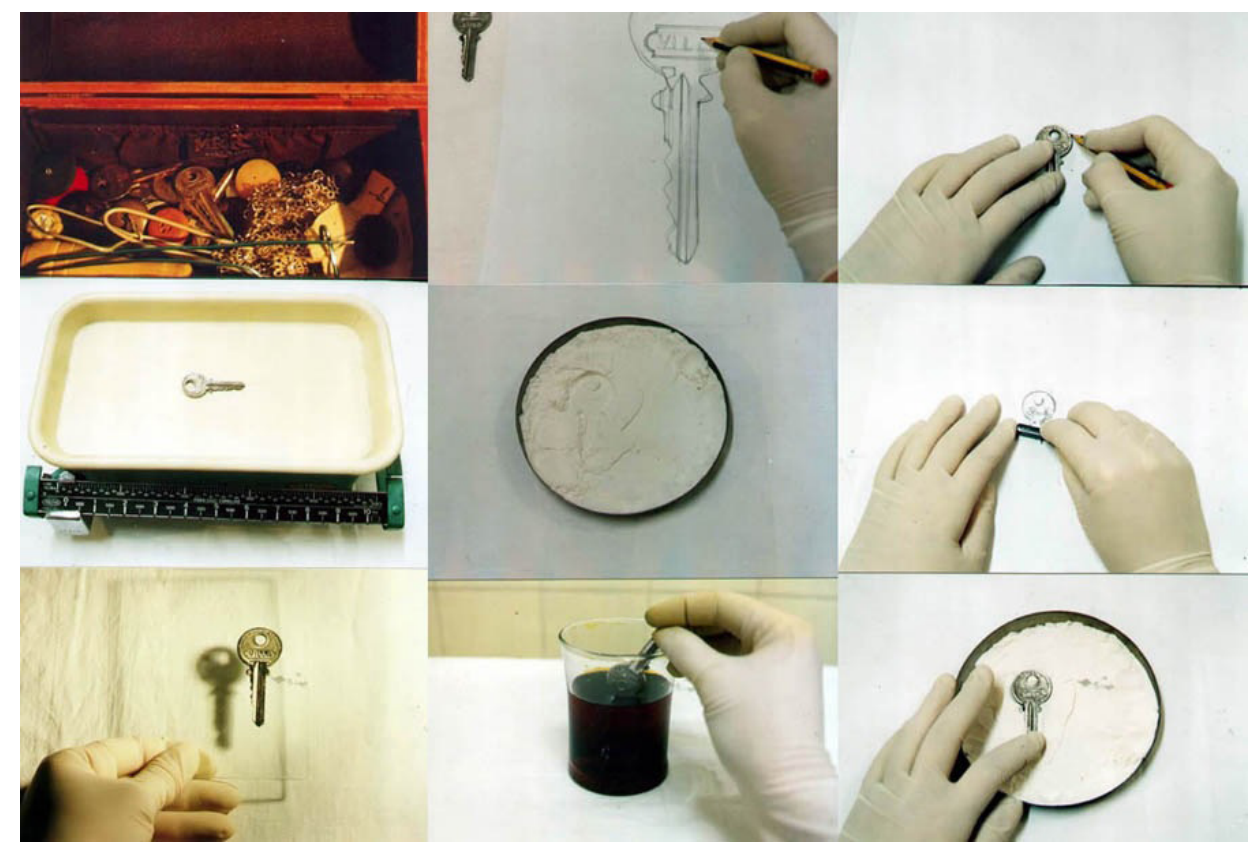

Imagen 1 - Proyecto Casa Museo (fotografías), Verónica Gómez, 2003-2005, Buenos Aires, Argentina.

En este sentido se presenta el intertexto de las instituciones museales apócrifas en las artes visuales, como el célebre Museo de las Águilas de Marcel Broodthaers, pero en este caso el objetivo no es poner al descubierto lo absurdo o lo disciplinario de estos dispositivos, sino jugar con ellos en un plano ficcional para producir determinados cursos de acción. Por otra parte, es interesante señalar que, ya en el funcionamiento doméstico, esa habitación estaba destinada al desarrollo de un archivo de la memoria familiar siendo un cuarto desafectado de la circulación utilitaria habitual. En este sentido, la artista señala:

[...] si bien estaba dentro de la casa, estaba desconectado del ritmo cotidiano, del uso práctico, como el uso que se le dá a una cocina, a un dormitorio, entonces ya había algo muy ficcional, cuando encontrabas el espacio era un escenario y yo era un personaje ahí.

Hay una anécdota familiar que explica la desconexión de dicho cuarto en la lógica utilitaria de la casa. La habitación se preparó para la llegada de unos parientes de España que vendrían a reunirse con 
sus abuelos, el encuentro nunca se produjo. Su abuelo comenzó a dormir la siesta allí; en esa misma cama, fallece años después. Uno de los objetos analizados es justamente una placa conmemorativa de su muerte. Cuando este segundo piso de la casa quedó deshabitado, los objetos empiezan a convocar la ausencia de sus habitantes, constituyéndose en sus improntas fragmentarias. Entonces, el dormitorio se pobló de diversos recuerdos familiares, tanto de sus abuelos como de su padre y se convirtió en una especie de santuario familiar. Despojadas de su utilidad, las cosas devinieron en marcas metonímicas de los personajes construidos en las anécdotas familiares:

[...] era un espacio desocupado pero al mismo tiempo estaba superpoblado de objetos que remitían a la ausencia también, esto era fuerte. Estaba lleno, todo lo que había en la casa eran reliquias, yo les digo reliquias, pero eran objetos que pertenecían a la vida cotidiana de mis abuelos. No sólo a la vida cotidiana de mis abuelos sino a mi infancia porque es una casa que yo conocía muy bien.

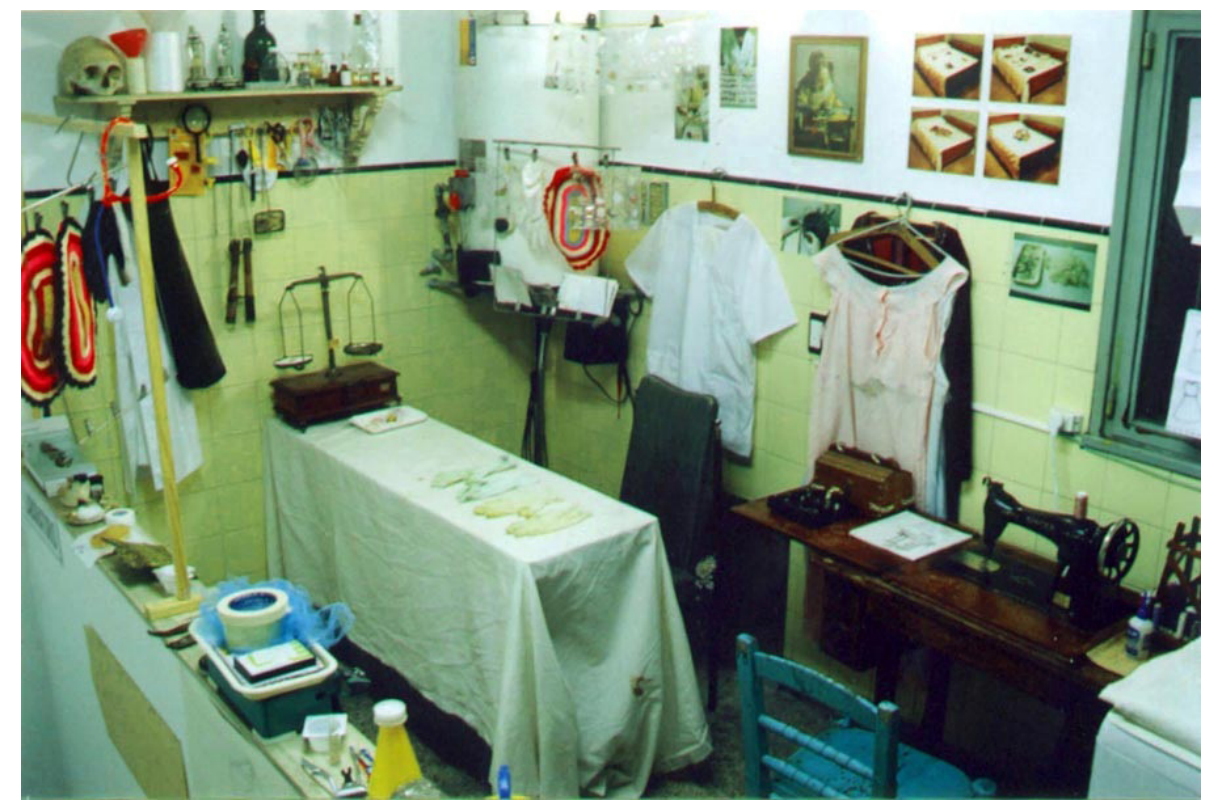

Imagen 2 - Proyecto Casa Museo, Verónica Gómez, 2003-2005, Buenos Aires, Argentina.

En la red documental en torno a dichas reliquias emerge la narrativa familiar que asume diversos pliegues temporales, uniendo la vida de los antecesores con la experiencia propia en un saber saturado sobre los objetos que se (re)presentan como una escenografía autorreflexiva. Verónica encuentra en estas construcciones de la vida cotidiana un aspecto teatral o ficcional, aludiendo a la capacidad figurativa de dichas construcciones ${ }^{3}$. Este pliegue temporal de los relatos familiares puede encontrarse en un repertorio de motivos 
que refieren a las etapas de la vida donde nacimientos, juegos infantiles, experiencias de la vejez y la clausura de la muerte cruzan los relatos de vida de la generación de sus abuelos, de sus padres y la de ella misma. En la presentación de esta temática emerge una escena enunciativa marcada por una posición contemplativa, retrospectiva e introspectiva ligada a un ethos melancólico ${ }^{4}$. Esto se hace palpable en el diario de observaciones del proyecto: "Estoy tan triste porque las cosas se han desvencijado, han roto el hilo que las conectaba con los acontecimientos", "La luz se ha congelado y será siempre la misma y siempre la última", también aparece en la transcripción de una sesión de terapia: "Otra vez la soledad... Será porque siempre te ves de afuera" o la cita de Bachelard: "[...] la casa del pasado se ha convertido en una gran imagen, la gran imagen de las intimidades perdidas". Dicho ethos melancólico se une al carácter fragmentario de los vestigios recolectados: como define Calabrese (1999, p. 88), el fragmento es un pieza de bordes accidentados que da cuenta de una fractura que lo originó, una pieza que evoca una totalidad perdida. Bordar lineas entre estos fragmentos, recomponer el hilo roto que las conectaba con sus contextos es inscribirlos en nuevas narrativas, es enhebrar las experiencias de distintas generaciones, es recomponer también, líneas espacio-temporales de vivencias colectivas jalonadas por la inmigración, el desarraigo y la tristeza 5 .

La prosecución de la investigación motiva casi inmediatamente la generación de nuevos escenarios dentro de la casa: un laboratorio montado en el lavadero contiguo a la habitación de huéspedes y la oficina, centro de la producción de inventarios, fichas, diarios de observaciones y correspondencias, entre otros documentos. El mundo intimista y solitario de Casa Museo pronto se abre al intercambio con otras personas, sirviendo de plataforma para colaboraciones artísticas, donde los participantes son invitados por correspondencia sometiéndose a diversas reglas que el organismo apócrifo instituye. Dicho flujo alimenta la creación de protocolos que multiplican las instancias narrativas junto a la aparición de personajes ficcionales como la jefa y la ayudante del laboratorio junto a la secretaria y el portero. En este marco se desarrollan las Jornadas de Experimentación que incluyen acciones como la disección y reconstrucción de una muñeca, el montaje de diapositivas familiares, la fabricación de fenómenos climatológicos y minimos desplazamientos de objetos y muebles, entre otras acciones que evocan infantiles juegos y experimentos 
científicos. En el laboratorio se llevan a cabo operaciones como curar a un pez de plástico y a una planta, la extracción de color a partir de flores, pesar una lágrima y, nuevamente, la obtención de vestigios de objetos realizando calcos y mediciones. Como expone Valeria González (2010, p. 101), el proyecto condensa motivos dicotómicos como la experimentación científica y la anacronía de cierta educación sentimental, la fijeza de reglas institucionales y la libertad del juego, la cercanía de la amistad y la distancia del contrato.

Resulta interesante señalar el carácter particular de estos procesos colaborativos. Estas instancias de conversación e intercambio desde las estéticas contemporáneas, como la estética relacional formulada por Nicolas Bourriaud (2008), pero también en los planteos de Grant Kester (2004) o Reinaldo Laddaga (2006), se presentarían como la generación de vínculos directos que operarían en la inmediatez teniendo como paradigma la comunicación no descontextualizada de la oralidad. Por el contrario, aquí siempre se presenta cierto detenimiento, emerge un grado de incomunicabilidad irreductible. En una carta dirigida a la artista Florencia Levy, participante de las Jornadas en el 2004, puede leerse:

Coincido plenamente con la analogía que establece Ud. entre el grado de incerteza de los resultados obtenidos de una medición y la pérdida que se produce inevitablemente en el intento de transmitir la experiencia de ciertos estados o percepciones a través del lenguaje. Me atrevo a arriesgar que es justamente ese desfase o pérdida lo más interesante de los proyectos en los que trabajamos actualmente, aún cuando conlleven cierto grado de resignación ante aquello que resulta al fin y al cabo incomunicable.

Mientras que en las estéticas relacionales el intercambio privilegia una comunicación directa que elimina la mediación de los textos, esta experiencia, si bien también propone una lógica procesual (todas sus instancias conforman la propia obra como proceso), paradójicamente se ancla en la mediación y el desfase del texto escrito y en la distancia introspectiva de la contemplación haciendo foco en lo significativo de lo incomunicable.

Esta ficción doméstica, esta reelaboración del site-specific en clave íntima que se alimenta de la particularidad de los entornos habitados y de los relatos familiares nutridos de la exploración biográfica se encuentra presente en otros trabajos de la artista. Podemos mencionar, por ejemplo, el proyecto Habitaciones disponibles para señoritas (2008) que fue el resultado de un proceso donde se aplicaron 
ciertas herramientas similares como el dibujo y la escritura de diarios personales alrededor de otra circunstancia biográfica-habitacional, la estadía de la artista en una pensión para señoritas en la ciudad de Buenos Aires. Allí Verónica trabajó sobre los relatos de sus vecinas manteniendo conversaciones, "[...] entrar a la pensión fue como abrir un libro donde cada habitación era un capítulo, una historia de vida" según sus palabras. El proyecto se interrumpió cuando terminó su estadía en la pensión. Las técnicas de la entrevista y la presencia del relato biográfico reaparecen en otro proyecto como Servicio de retratos de Mascotas que realiza desde el 2010. Aquí se desarrolla "[...] una exploración estética de la personalidad de tu mascota" mediante entrevistas a sus dueños en el entorno que habitan, donde se intenta definir la personalidad del animal retratado. El formato final de la experiencia es una pintura que incluye los objetos que sirven de escenografía al personaje, tal como estipula el contrato pintora-cliente.

\section{Gabriel Baggio: heredar, citar, transformar}

Desde el 2001, Gabriel Baggio se encuentra con personas para conversar en espacios públicos mientras elabora un gran tejido que adquiere la extensión correspondiente al tiempo de dichas charlas acumuladas ${ }^{6}$. Así su extensión funciona como un índice de la temporalidad de estos encuentros donde se comparte un momento y una copa de vino. La performance Conversación sí propicia un cara a cara entre el artista y los conversadores-espectadores, la acción de tejer metaforiza la construcción de redes, de contactos interpersonales.

Otra performance fundacional en el trabajo de Gabriel fue Sopa, realizada por primera vez en el 2002. Su madre, su abuela y él mismo realizaron tres versiones de una receta familiar que fue entregada al público en pocillos de diferentes colores con el objetivo de diferenciarlas. La acción se inicia descontextualizando el rito doméstico de su ámbito íntimo, la tradición familiar también sufre modificaciones al asignarle a un miembro masculino el rol de realizar la sopa. Luego de dos horas de cocción, tres catadoras profesionales clasificaron los respectivos platos definiendo al de la abuela como el más dulce, al de la madre como el más contundente y nutritivo, y al del artista como el más ácido. El efecto de puesta en escena de las tres cocinas se resalta por medio de conexiones de gas que evidencian el motivo del entramado, los vínculos y las filiaciones, además el efecto de representación se potencia en la división escénica entre 
protagonistas (los representantes de las tres generaciones) y el público observador-degustador.

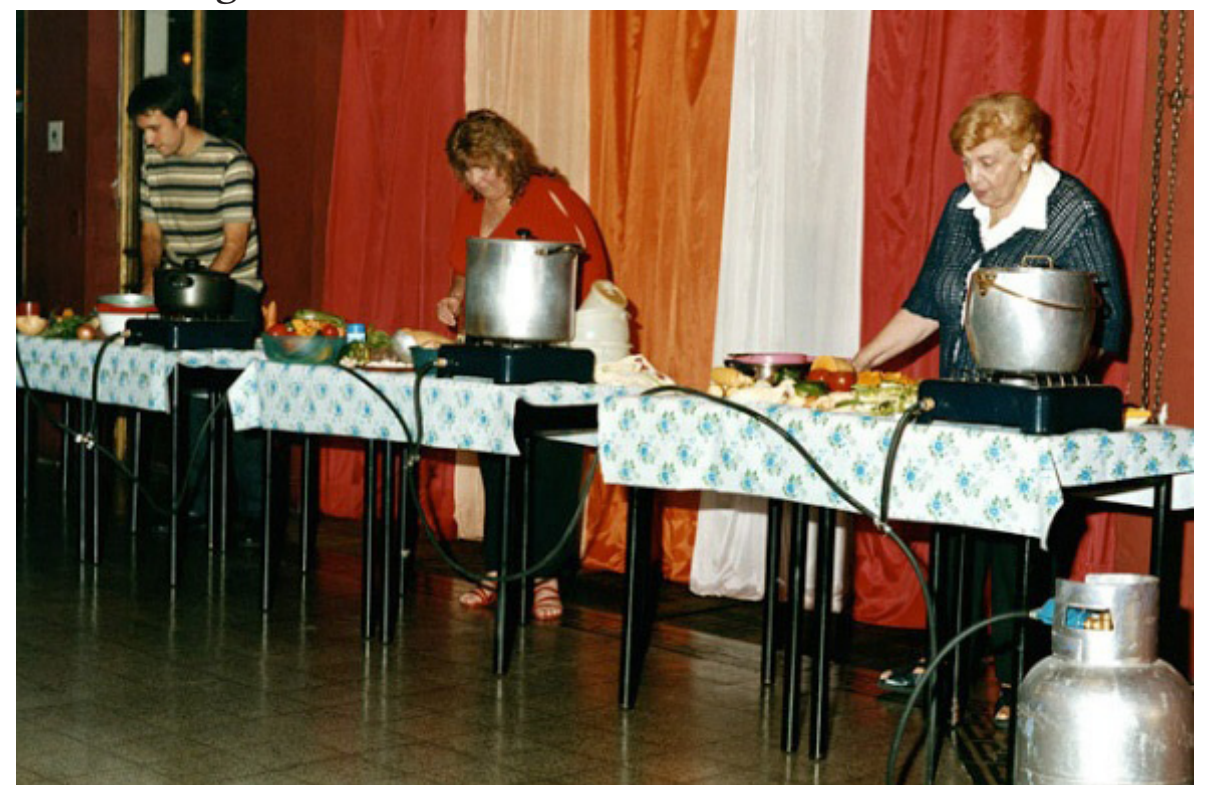

Imagen 3 - Performance Sopa, Gabriel Baggio, su madre y su abuela, 2002, Buenos Aires, Argentina.

Entre la escena oral, cotidiana, popular y familiar de la cocina y su traducción al lenguaje científico-profesional de la escritura descriptiva de los componentes químicos emerge una de las problemáticas más recurrentes de su producción, el tema central de esta performance, el interrogante sobre los mecanismos semióticos que determinan la transferencia y transformación de los textos culturales heredados. A diferencia de la icónica obra de Rirkrit Tiravanija Untitled (Free) de 1992, donde se convirtió una galería neoyorkina en una cocina que sirve gratuitamente curry tailandés con el objetivo de generar una instancia de encuentro interpersonal directo (obra paradigmática del estar-juntos de la estética relacional), aquí el fin es reparar justamente en las mediaciones de estas prácticas interpersonales ${ }^{7}$. Esta tematización, la herencia de prácticas y saberes, entendida como una problemática transtextual (Genette, 1989), será una de las perspectivas de más largo aliento en la obra del artista. En este sentido, podemos entender sus palabras:

A partir de esta obra se abrió un terreno de trabajo claramente más delimitado, que, por el momento, gira en torno a la construcción de las tradiciones, los roles, las reglas, los rituales e incluso la memoria a partir de las acciones cotidianas ${ }^{8}$.

No se trata sólo de evocar las realizaciones de los antecesores, sino de explorar la complejidad de las operaciones intertextuales que 
determinan estas herencias imperfectas, donde recuperación, lectura y olvido establecen las transformaciones de reglas y ritos. Al respecto, el artista explicita:

[...] tomo el concepto de que la transmisión oral no es literal, no hay una reproducción exacta. En ese sentido, en realidad, la transmisión es perfecta porque ya es inherente a la propia transmisión oral que no sea exacta $[. .$.$] No hay manera de que eso sea perfecto, o sea, para mí$ es perfecto en tanto es imperfecto.

Dicha indagación sobre las operaciones semióticas que sustentan las memorias culturales se combina con otros elementos también determinantes en el recorrido de Gabriel. Mencionaremos tres núcleos que las estéticas modernas negaron en su momento y que su obra vuelve a traer a escena. Desde una mirada de género, la reivindicación de actividades tradicionalmente menospreciadas en su asociación a roles femeninos como la cocina o la costura. En relación directa con este primer punto, la revalorización de actividades artesanales que pueblan nuestra existencia cotidiana antes eclipsadas en el terreno de los discursos estéticos modernos que privilegian la contemplación, que ahora se han jerarquizado en las prácticas del craftivism (Buszek, 2011). Finalmente, el retorno hacia una consideración pre-kantiana de la estética como una aisthesis, terreno de la percepción y la sensación como productoras de sentido?

Otro vector de su producción, que también encontramos en la experiencia de Verónica antes analizada, es el eje que une la experiencia personal con la historia colectiva marcada por la inmigración, desde esta perspectiva el artista indica:

Mi trabajo parte de un lugar altamente autorreferencial, y la primera demanda que supongo le exige al espectador sería la capacidad de trasponer lo que pareciera mío pero termina haciendo eco en miles de historias parecidas. Trabajar sobre la construcción de la memoria, puede leerse tanto dentro de un núcleo familiar como de un todo social ${ }^{10}$.

Reconstruir el trayecto entre lo personal y lo social es una de las aristas del proyecto Nieto (2002), una instalación presentada en la casa de la abuela paterna del artista. El proyecto, como en el caso de Casa Museo, lee la habitabilidad que propone el departamento de su abuela. En la sala de estar, espacio representacional por excelencia del ámbito doméstico, es un lugar público en el espacio privado ${ }^{11}$, en términos de Erving Goffman (1981) se trata de un front stage. Allí se exhiben un conjunto de piezas cerámicas, así como videos de sus performances y un panel con el árbol genealógico femenino. En 
este living, donde su abuela muestra usualmente sus recuerdos y un repertorio decorativo, se encuentran emplazados estos objetos, exentos o colocados sobre el muro, producidos con las herramientas que su abuelo, Luis Baggio, elaboraba para que su abuela preparase la pasta. La serie se titula Sedimentación del aprendizaje alimenticio (2002). Al lado del objeto escultórico se presenta la herramienta indicando su autoría. Al respecto, el artista consigna:

[...] a mí me interesa lo que implicó en la historia de vida de esa persona esta acción, yo me detengo ahí. Lo que implicó en la relación entre mis abuelos, que mi abuelo le hubiese hecho las herramientas para que mi abuela cocinase para él [...] Me interesa entender lo que implicó en la relación entre ellos el hecho de haber puesto en práctica un oficio.

En esta operación descubrimos un procedimiento característico: la confección de objetos producidos por moldes que, en la impronta de su misma factura, se revelan como huellas de un artefacto originario junto con la presentación de la pieza cerámica resultante. Esta estrategia la reencontramos en la performance e instalación $L o$ dado (2006), donde hallamos tres platos preparados nuevamente por la abuela, la madre y el artista que se encuentran replicados por la misma técnica de moldeado con cerámica. El contacto se vincula a la herencia, al contacto uterino constituido como un lazo nutritivo entre madre e hijo ${ }^{12}$. Contacto que también se asocia a la dimensión intertextual de la cita que, como consigna Calabrese (1999), puede pensarse como calco, en tanto copia o plagio.

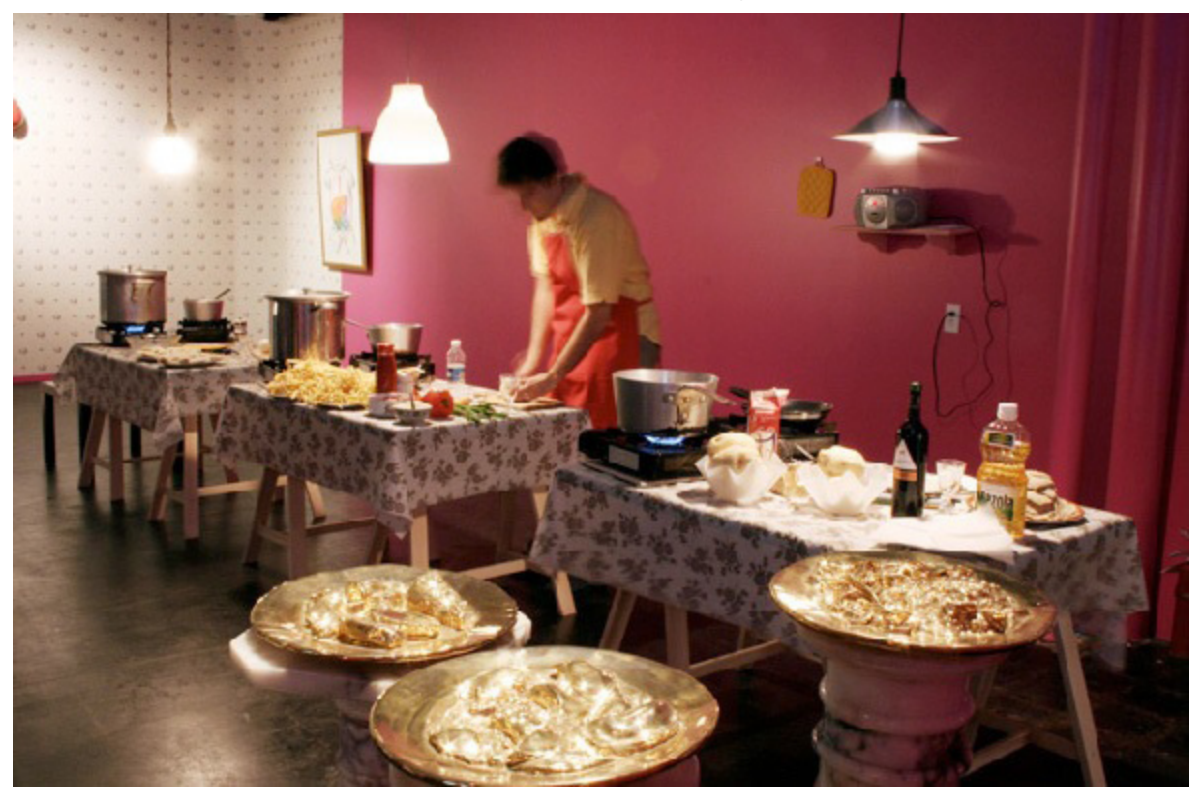

Imagen 4 - Performance e instalación Lo dado, Gabriel Baggio, 2006, Montreal, Canadá. 
Volvamos a Nieto. Atravesando el espacio público de la sala de estar nos adentramos en la privacidad del dormitorio, el back stage (Goffman, 1981). Allí se encuentra la obra Gula maternalpaterna (2002) que consiste en dos autorretratos fotográficos que muestran al artista desnudo en posición fetal sobre dos contornos, que evocan las imágenes del útero y el ataúd, conformados en un caso por knishes, y en el otro por fideos. Ambas comidas recuerdan a la tradición gastronómica judía (por parte de la abuela materna) e italiana (por parte de la abuela paterna) entrelazadas en su historia familiar. La dos fotos son colocadas en el piso, ocupando el mismo lugar donde estaría ubicada una cama matrimonial. Cuando el artista cocinó la pasta para producir la fotografía retrató a sus dos abuelas y colocó esas imágenes en las mesas de luz acompañando al díptico fotográfico. En este espacio de intimidad y exposición biográfica emerge una inscripción significativa a la historia colectiva, proyectando la propia historia de vida en el devenir social. La cocina también fue ocupada en esta experiencia funcionando como un espacio dispuesto para el encuentro en la acción de compartir el alimento, ńoquis con tuco, en un ámbito de sociabilidad cercana y acotada.

En las performances Procesos de aprendizaje, producidas desde 2006, también se tematiza la problemática de la transmisión de saberes y prácticas mediante un trabajo procesual donde el aprendizaje es la misma experiencia artística. Se trata de hacer foco sobre instancias de enseñanaza y adquisición, por parte del artista, de alguna habilidad manual siguiendo la problemática de las herencias culturales en el continuo social. Las primeras performances tuvieron como contexto el evento Desde el alma (2006) desarrollado junto a Carolina Katz y Zoe Di Rienzo nuevamente en una casa particular en la ciudad de Buenos Aires. Allí, Gabriel aprendió a preparar kujelles a partir de las enseñanzas de su abuela y a tejer una agarradera al crochet. La experiencia se repitió hasta la actualidad trabajando con personas fuera de su entorno familiar en la incorporación de saberes de otras regiones. Se desarrollan aprendizajes gastronómicos como la preparación de picante de pollo, fideos de espinaca con estofado, bollitos pelones y adiestramientos vinculados con prácticas artesanales en desuso como la realización de una olla de chapa batida o el taraceado en madera.

En el mural cerámico Motivo para sábana (variaciones cromáticas y formales) del 2009, se transpone el patrón ornamental de 
una sábana de la abuela del artista que recuerda de su infancia. Es interesante entender aquí cómo el recuerdo es tematizado como un acto de objetivación transformadora. En esta perspectiva podemos entender sus palabras:

[...] cuando vacié la casa de mi abuela, fuimos con mi padre y encontramos un pedazo de tela que era de una cortina de cuando yo era chiquito. Ni bien la vi la reconocí inmediatamente, era una tela de flores que revestía los sillones y las cortinas. Yo me acordaba de unas flores divinas, súper vivaces y en ese momento las veía y eran depresivas, un fondo blanco con una flor marrón. Igual guardé el pedacito de tela, cinco años después recordando eso y ordenando las cosas, pensé en pintar las flores con los colores que recordaba, no sabía cuales eran pero los que tenía seguro que no. Entonces, hice el dibujo y los pinté de colores fosforescentes.

Aquí nuevamente aparece el potencial transformador de la memoria en el recuerdo de los legados. Desde una perspectiva similar podemos referirnos a la exposición Elogio de la profanación (2011) donde también se desarrolla un análisis intertextual de los legados familiares. La muestra tiene como pieza central un objeto cerámico esmaltado en oro, nuevamente realizado mediante la técnica del molde, que representa la imagen de un injerto. Como es sabido, esta técnica botánica consiste en poner en contacto los tejidos vegetales en vías de formación que se encuentran debajo de la corteza. La imagen procede, una vez más, de los libros de jardinería de su abuelo vistos durante la infancia del artista. La figura evocativa del injerto nuevamente pone en relación el tema del lazo nutritivo, como un encausamiento de las redes vitales, con la idea del contacto, en tanto calco, que deja translucir las huellas de ciertos textos en otros. En este sentido, Genette señala que la transtextualidad, de manera general es "[...] la presencia efectiva de un texto en otro" (1989, p. 10). Así, la obra de Gabriel se propone reconstruir las secuencias de imágenes mostrando la presencia efectiva de unas en otras explorando los objetos, saberes y prácticas que le son cercanos, con los que ha establecido contacto. En esta exhibición también presenta la pintura Tempestad. Giorgione - Sotto - Baggio (variaciones cromáticas y formales) que enlaza la obra de Giorgione, una imitación realizada por el copista Sotto para su abuelo con la reproducción realizada por él mismo mediante los escolares procedimientos de la témpera y el papel. El sendero establecido recorre la paradigmática obra del pintor veneciano con la escena de la copia en la casa de sus abuelos inmigrantes 
italianos y el recuerdo actual de esta imagen. La evocación, con los mencionados procedimientos infantiles, es el último eslabón en esta secuencia de contactos explicitada por la obra.

Así se alude a una actividad cercana a la historia del arte que da cuenta de esa presencia efectiva de unas imágenes en otras referenciando una práctica iconográfica que entiende que dichos rastros señalan la evidencia de contactos, el testimonio de vínculos y proximidades en un paradigma indiciario (Ginzburg, 2000). El indicio del contacto ocurrido delata las cercanías entre diversos textos, objetos, prácticas y saberes, devela redes densas en las que se constituye la cultura. El iconógrafo, en una actividad detectivesca, instituye itinerarios de objetos reconstruyendo la antigua escena cultural que hoy se observa fragmentada, dispersa e irreconocible. La pesquisa en el caso de esta Tempestad plagiada apunta a reconstruir una microhistoria de lecturas; la exploración evidencia una trama de proximidades en la que se insertó dicho objeto, muestra una circulación concreta, señala unos usos particulares. Así esta obra, al evidenciar los usos de imágenes correlativas, también enlaza las instancias generacionales del abuelo, la mirada del nińo y el actual artista devenido en analista de las redes culturales.

\section{Ana Gallardo, Contar y Producir Experiencias}

Tres de las primeras producciones de Ana Gallardo funcionan como un pronunciamiento sobre uno de los mayores problemas de salud pública en Latinoamérica, que atenta contra la vida de las mujeres: el aborto ilegal. Manifiesto escéptico (1999), Material descartable (2000) y Politicas corporales (2002) son tres instalaciones que tratan esta problemática. En el primer caso, se exhiben suspendidos sobre la pared, sujetos con cinta de pintor, diversos objetos domésticos; "[...] los objetos de uso cotidiano son los elementos que se usan como instrumental quirúrgico y descartable" (Gallardo, 2010, p. 14) en el aborto ilegal. En el segundo caso, también se suspenden ramos de perejil atados con hilos de coser, también utilizados como procedimientos abortivos por mujeres pertenecientes a las clases populares de nuestra región. En la última obra, nos encontramos con una madeja de agujas de coser, otro utensilio alusivo al aborto casero. Aquello que es invisibilizado, confinado a lo doméstico, a lo personal, al terreno íntimo o señalado como meramente biográfico 
(en el despectivo sentido que niega politicidad al problema) como es el aborto ilegal se pone en escena. Así se reivindica la celebre premisa por la cual lo personal es social y político. Estas primeras obras son muy diferentes a su posterior desarrollo, pero ya presentan ciertos espacios de exploración.

Otro proyecto de los primeros tiempos que marca un camino más definitivo en su trayectoria es Autorretrato (2001), que se compone de un reproductor de sonido junto a un banco que invita a escuchar un famoso bolero cantado por Gallardo a capella. La operatoria del retrato es recurrente en la producción de Ana, en sus palabras: "En realidad yo me considero una retratista; yo hago una forma de retrato contemporáneo; entonces cada una de estas formas es un retrato o un autorretrato"13. La letra de la canción rememora un desengaño amoroso y habla de la posesión de objetos que recuerdan ese amor. Así se consolidan ciertos vínculos entre voz, canto, el recuerdo e historia de amor a los que volverá permanentemente.

La instalación Patrimonio (2003) fue otro trabajo que trazó fuertemente su recorrido. Allí se presentan varios objetos domésticos de la propia artista como un piano, una antigua bicicleta, sillas y silloncitos entre otros muebles gastados asidos nuevamente a las paredes de la galería con cintas de pintor. En otro muro se sitúan dibujos de objetos domésticos cotidianos que parecen conjurados en la insistente repetición de la acción del dibujar. Estos trazos le permiten volver apropiarse de estos objetos, detenerse frente a ellos es inscribirse nuevamente a ellos, en un dispositivo similar al practicado en Casa Museo. Al respecto Ana señala:

Cada objeto tenía un relato, cada uno tenía una historia personal. Esta muestra tenía en la pared del frente dibujos de los objetos, en esa época yo quería retomar esa práctica que había perdido y con esta muestra lo que hice fue dibujar cada uno de esos objetos, intentando hacer un estudio académico. En mi fantasía yo veía que cada objeto tenía una relación conmigo y con ese estudio, justamente, yo podía apropiarme de esa historia. No me deshago nunca de todo eso, yo cuando trabajo voy sumando continuamente. 


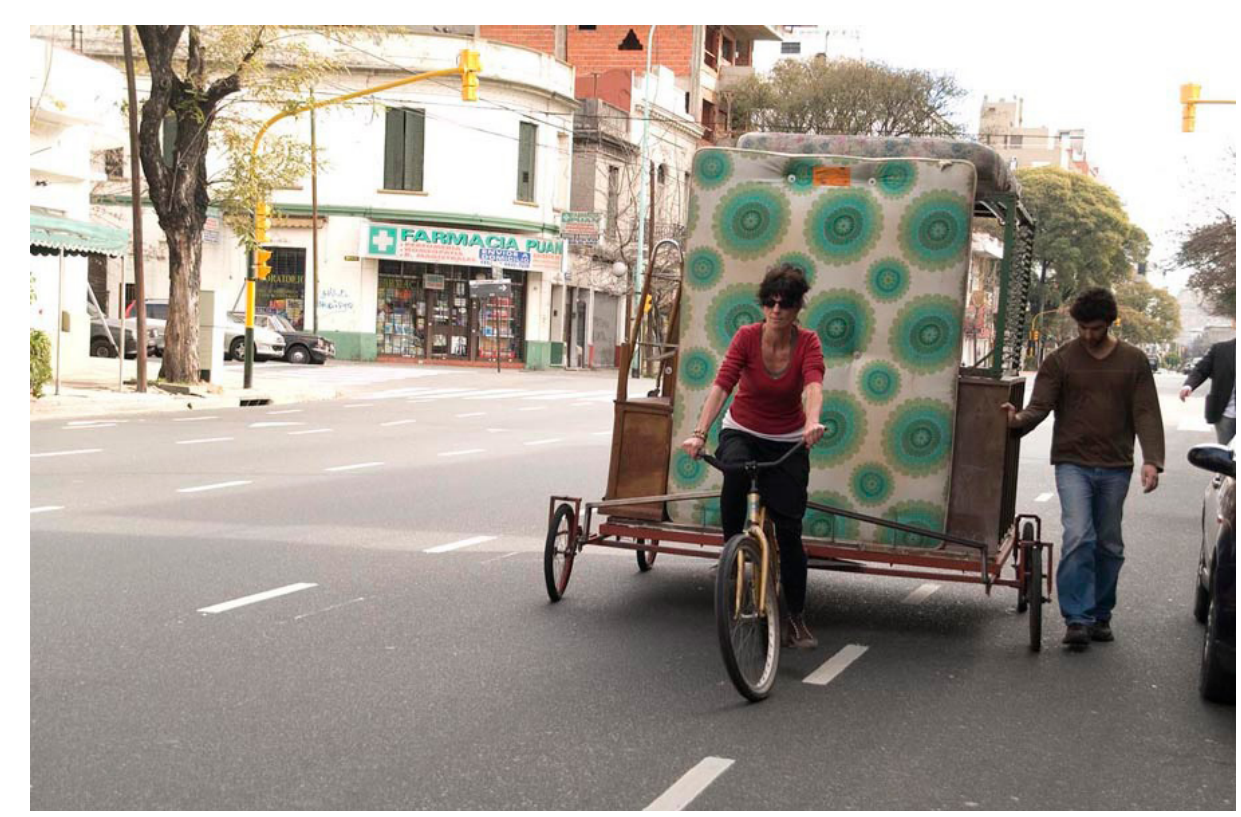

Imagen 5 - Performance Casa rodante, Ana Gallardo, 2007, Buenos Aires, Argentina.

Dicha instalación tiene un vínculo muy estrecho con la video performance Casa Rodante producida cuatro años después. El video registra el tránsito de la artista y su hija junto a otros artistas y amigos arrastrando con una bicicleta diversos muebles usados en un trayecto de ocho kilómetros. En esta ocasión, se presenta también una anécdota autobiográfica contextualizando la obra: durante el 2006 Ana Gallardo y su familia se mudan luego de un año de pasar por distintos espacios transitorios. Durante ese año acumulan sus pertenencias en un galpón. Luego encuentran una casa, pero muchas de sus pertenencias no caben en el nuevo lugar. Estos objetos son parte de herencias y recuerdos, en Patrimonio y Casa rodante se utilizaron esos objetos, así lo recuerda la artista:

Se usaron los mismos objetos. Mi casa siempre estuvo compuesta por cosas que nos estaban regalando. Cuando volví de México no tenía nada propio más que los objetos que fui guardando a lo largo de mí vida, de los afectos, mis amores. Yo les dejaba mis cosas a mis amigos en Buenos Aires. Cuando yo volvía de México, lo que quedaba era lo que componía mi casa, una acumulación de basura, basura y de recuerdos.

La exploración por el espacio biográfico no se detiene únicamente en su propia vida, en simultáneo empieza a explorar su círculo íntimo, marcado por los legados familiares, produciendo obras en soporte videográfico que documentan experiencias concretas como Mi tío Eduardo (2006) o Mi padre (2007), allí la artista escribe la 
vida de los otros. La primera obra parte de una anécdota familiar: el tío Eduardo nació en Granada, España, y hace medio siglo vive en Rosario, Argentina. La propuesta original consistía en realizar un viaje juntos. Planificaron un itinerario que situaba geográficamente los recuerdos del tío. A último momento, Eduardo decide no viajar; la artista emprende el recorrido con el mapa que realizaron juntos, donde filma los paisajes afectivos con los que él quería reencontrarse. En el resultado final, el video muestra, en un plano medio, el rostro del tío contemplando en su cocina la proyección de los lugares visitados. Mi padre (2007), experiencia que también tuvo como resultado una video-instalación, recorre senderos similares, ya sea por sus técnicas de producción, como por el espacio biográfico en común que transitan. En esta ocasión, la artista encuentra un artículo que casualmente retrata la llegada de sus padres a la ciudad de Rosario procedentes de España. Se trata de un viaje en tren en el momento en que su madre ya se encuentra embarazada. Vemos el rostro del padre, quien lee el artículo enterándose de su existencia en el mismo momento de la lectura. En ambos videos, se observa una calidad de realización cercana a la práctica del video doméstico; se trabaja con una manera de hacer rigurosamente no-profesional en un terreno siempre fronterizo con la especificidad de los lenguajes constituidos. Esta premisa también se acerca al recurrente ejercicio del dibujo o al canto entendido como un hacer inmediato; se trata de prácticas, como las define Michel De Certeau, que operan en el espacio del otro, apropiándose de lo existente sin tener su centro en un dominio disciplinario. Así lo consigna Ana:

De lo que se hace con lo que no hay, como no tengo, como que nunca he tenido nada, nada. [...] Entonces todo lo que hago es apropiarme de todo lo que hay alrededor, de las historias de los demás, de los objetos de los demás, yo no tengo nada, todavía sigo sin tener nada. De hecho yo no estudié, todos mis lenguajes son apropiados, fui robando. Incluso la cámara me la prestaron, fui con esa cámara y yo no tenía idea de como ponerla, después no podés arreglarlo en la edición, esa precariedad tiene que ver con el rodaje. Tengo urgencia y no tengo paciencia, no tengo tiempo para esperar que un dibujo lleve un mes de trabajo, lo hago y luego hago otro y otro igual. No me importa, creo que no me intereso por ninguna técnica, a veces pienso que si domino una técnica voy a estar perdida.

Paralelamente desarrolla plataformas de intercambio con personas que tienen la finalidad de indagar en sus recuerdos, generalmente trabaja con mujeres de más de cuarenta años. En estas colaboraciones 
se documentan sus recuerdos pero también se generan experiencias en presente que determinan el resultado final. En la primera de estas producciones, Tía Rosita (2004), se despliegan técnicas que luego serán utilizadas en los siguientes proyectos. El tópico que hará emerger diversas narrativas, procedentes de géneros discursivos primarios originarios de la conversación, es el de las relaciones amorosas. La importancia del tema, el amor, radica en su capacidad de convocar narrativas de las historias de vida. La obra se basa en la reconstrucción, por parte de la tía de la artista, de su historia de amor más importante. La artista describe del siguiente modo su metodología:

La historia de amor no me interesa en sí misma, a la hora de relacionarme con ellas (casi todas son mujeres) me resulta una buena entrada. En realidad mi pregunta, y lo que intento indagar, es: ¿qué pasa a esa edad y con la cercanía a la muerte?

Durante dos meses Ana y su tía se reunieron a revivir aquella historia, se produjo material fotográfico y grabaron todas las conversaciones, desarrollando un proceso de edición de los materiales que se constituyó como el vector del proceso. Luego se exhibieron el audio y las fotos de ese transcurso junto a dibujos en carbonilla sobre el muro, producidos por la tía, que representaban objetos y lugares que escenifican dicha historia. La documentación de estas narrativas siempre implica una actividad procesual por la cual la escritura es en sí misma producción de experiencia. Esta escritura biográfica nunca es transparente, pura transcripción, es en sí misma un proceso de producción de vivencias que habilita el relato, el ejercicio de una temporalidad enunciva dada en el acto de contar y contarse la vida donde se participa como personaje y narrador simultáneamente (Parret, 1995, p. 103). Así se dan dos niveles de exploración, por un lado el desarrollo de técnicas de transcripción de lo dicho, como la producción de una suerte de historia oral, que reivindica la memoria personal. Por otro, se generan encuentros interpersonales que configuran aquello que es contado.

La lógica implementada luego se extiende a personas más alejadas de su entorno personal. En el trabajo La hiedra (2006) se indaga en las historias de vida de cinco mujeres tomando nuevamente como hilo conductor sus relatos sobre el amor. El título de la obra hace referencia a ese vínculo afectivo y, simultáneamente, tematiza el propio proyecto que necesita parasitar los relatos de dichas mujeres desde un apropiacionismo intimista. En estas historias siempre se percibe un aspecto dramático entendido como un punto en común 
a todo recorrido biográfico. Por eso, Ana indica que "[...] me gusta la actividad de buscar personas y hablar con ellas sobre sus historias de vida. En los actos cotidianos y en las relaciones afectivas, percibo hechos artísticos". (Gallardo, 2010, p. 48). El texto de la curadora de la exposición, Victoria Noorthoorn, subraya el carácter procesual de los vínculos que se generan donde se estimulan encuentros que determinan compromisos personales, así los relaciona con los desarrollos performáticos de las vanguardias históricas (el movimiento dadaísta), con experiencias de los sesenta en el plano nacional o internacional (el grupo Fluxus, las performances de Alberto Greco o el intertexto entre música y performance de John Cage) o iniciativas de la escena, digamos relacional, más contemporánea en Argentina (los proyectos colaborativos de Roberto Jacoby y de Fernanda Laguna) (Gallardo, 2010). Observemos de cerca la acciones realizadas. Una de las historias presentadas recoge el relato de Lidia Barreiro, de setenta y ocho años, quien al releer antiguas correspondencias privadas se reencuentra con una carta de despedida de un antiguo enamorado. A partir de este recuerdo genera un escrito y fotografía sus cartas. Otra historia que se presenta es la de Gabriela Zajur, de cuarenta y cinco años, quien retrata a su pareja de ochenta y cuatro ańos produciendo pinturas a partir de sus objetos y recuerdos fotográficos. En los dos ejemplos mencionados se adquieren durante el proceso de producción de la obra destrezas (escribir, pintar) que las mujeres no practicaban inicialmente. El ciclo se completa invitando al público a participar brindando objetos, textos, fotos o cualquier otro elemento que referencia a sus historias de amor. En la galería se ofrecieron recitales, proyecciones de video, un ciclo de clásicos del cine de amor y sesiones del tarot del amor. En estas actividades también se propicia una participación del público, intentando difuminar las divisiones entre espectadores y productores, gesto característico de las estéticas relacionales. Pero, a diferencia de algunas de las experiencias evocadas por la curadora, aquí el intercambio no puede definirse sólo como el contacto directo marcado por la inmediatez del cara a cara, en los procesos que se desarrollaron, tal como sucede en las colaboraciones de Casa Museo, los momentos de detenimiento e introspección son fundamentales, aquí las instancias de contemplación y soledad son determinantes. En realidad, se trata de combinar momentos de interacción y retraimiento, de proximidad y distancia, de la supuesta actividad de la acción con la aparente pasividad de una práctica pensativa. 


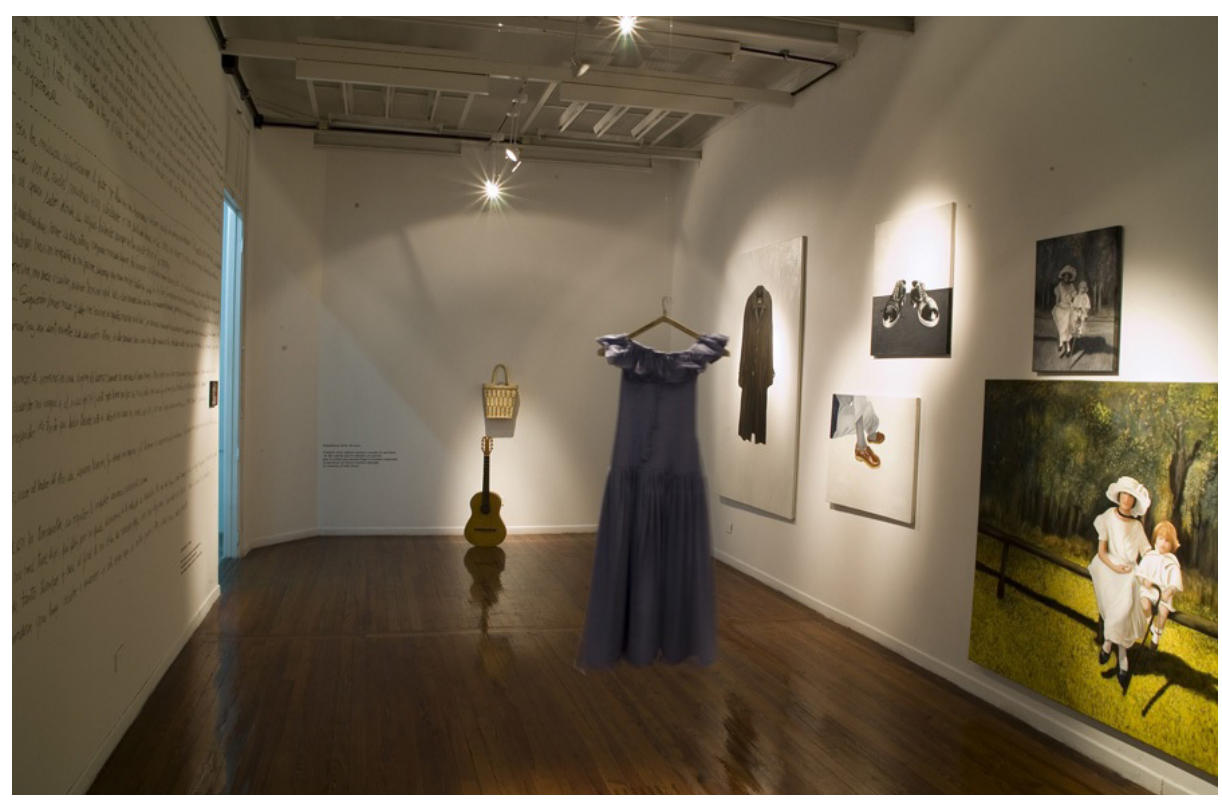

Imagen 6 - Exposición La hiedra, Ana Gallardo, 2006, Buenos Aires, Argentina.

Finalmente reseńamos dos proyectos que parecen marcar el rumbo de su última producción. En ambos casos la operatoria consiste en desarrollar un ready-made experiencial que recoge una práctica cultural existente en Latinoamérica para constituir un sistema colaborativo que funciona como una arquitectura utópica (Iglesias, 2010), donde resignificar el lugar cultural de la vejez. En el caso de El pedimento (2009), la práctica reapropiada es un culto procedente de la zona de Oaxaca en México, donde la gente ofrenda objetos modelados en barro representando sus pedidos en el santuario de la virgen de Juquila. El primer pedimento realizado por la artista se realizó con el barro de las orillas del río Paraná, en su ciudad natal, Rosario. Luego se produjeron diversos encuentros donde Ana invita a familiares, amigos y conocidos a modelar una pieza de arcilla con "su deseo más profundo, pero pensado en la vejez" (Gallardo, 2010, p. 91). El circuito del pedimento se ha ido extendiendo desde entonces, avanzando sobre distintas ciudades y países. La etapa final del proyecto prevé el traslado de las figuras de barro a Juquila en un recorrido terrestre. El proyecto Un lugar para vivir cuando seamos viejos (2008) propone repensar la idea de vejez en nuestra sociedad reelaborando las condiciones de vida en las que trascurre. Desmontando la discursividad social que define a la vejez como una etapa de carencia y deterioro, la artista junto a Mario Gómez Casas y Ramiro Gallardo proponen una redefinición del término desde una posición también biográfica: 
Somos personas de diferentes edades y con distintas actividades, algunos sin trabajo fijo ni ingresos regulares, tampoco tenemos bienes, no aportamos a la jubilación [...] Pero deseamos continuar con una buena calidad de vida, estar juntos, vivir cerca y no estar solos (Gallardo, 2010, p. 82).

El proyecto se planificó según tres etapas de realización. La primera es un momento de reconocimiento de prácticas sociales donde se investigan y documentan "[...] actividades que nos parecen posibles y necesarias para una buena vejez" (Gallardo, 2010, p. 82). El siguiente nivel consiste en la realización de un viaje por Latinoamérica para analizar posibles lugares donde instalar el geriátrico, finalmente el último momento es el de la concreción del proyecto. En la $29^{\circ}$ edición de la Bienal de San Pablo (2010) se presentaron los primeros resultados: se produjo un espacio de danzonera, práctica cultural popular en la Ciudad de México donde se monta una gran carpa que aloja una improvisada pista donde personas ancianas practican baile.

\section{Apuntes de la Lectura}

Como indicamos en el inicio, las experiencias analizadas acontecen en un horizonte de mayor porosidad e hibridación entre los géneros primarios y secundarios partiendo del diagnóstico de Arfuch (2010) sobre el espacio biográfico contemporáneo. Los proyectos de Verónica Gómez, Gabriel Baggio y Ana Gallardo documentan narrativas que fueron extraídas de la vida de todos los días, relatos autorreflexivos donde se construye la propia historia entramada en una red de diversos legados generacionales. Este funcionamiento, por un lado, se corresponde a la direccionalidad señalada por Bajtín (2005) donde los enunciados de las conversaciones cotidianas - a lo que nosotros podemos sumar desde una perspectiva no exclusivamente verbal los procesos de contemplación y las prácticas del hacer - son descontextualizados para restituirse en otra totalidad, la del proyecto artístico que se apropia de ellas para resignificarlos. Así, los recuerdos familiares de los abuelos de Verónica se vuelven a enhebrar en un nuevo horizonte que ya no pertenece al terreno de la vida cotidiana de sus abuelos; las prácticas de los oficios y tareas domésticas de los abuelos de Gabriel son (re)emplazadas en un análisis semiótico de las herencias culturales; las historias de amor de las mujeres entrevistadas por Ana Gallardo son absorbidas por una iniciativa que parasita sus experiencias para extraer de ellas sus narrativas. Esta operación desde 
la óptica de Bajtín no implica una radical discontinuidad en la que estos enunciados son absolutamente vaciados en su relocalización. Esta reelaboración permite otorgar a las obras artísticas un particular tono de época, habilitar un nexo entre enunciados simples y complejos que proyecta luz sobre el "complejo problema de la relación mutua entre el lenguaje y la ideología o visión del mundo" presente en la producción artística (Bajtín, 2005, p. 250).

Pero la porosidad entre enunciados simples y complejos se alimenta de otra circulación diferente a la contemplada por Bajtín. La obra de Verónica, mientras realiza estas actividades descontextualizadoras, paralelamente genera nuevos dispositivos de intercambio, por ejemplo, la producción de correspondencia es parte integrante de su trabajo y esta experiencia no es extraída del acervo familiar, sino efectivamente producida en una nueva trama de sociabilidad superpuesta al primer estrato documental. Lo mismo sucede en el caso de Gabriel, además de analizar usos y prácticas sobre los objetos ya dados, en sus procesos de aprendizaje o en sus conversaciones diseña un sistema que retroalimenta la producción efectiva de dichos acontecimientos que se dan en el presente del intercambio. En esta misma dirección, las experiencias que alientan los procesos de edición de las historias amorosas de Ana son devenires que abren instancias de diálogo y detenimiento introspectivo con otras personas. Sus mismos procesos de construcción implican la producción de géneros primarios dados en el diálogo. En definitiva, el carácter performático de estas experiencias dado en el horizonte de un presente y en una presencia efectiva promueve una hibridación que se da entre la distancia analítica descontextualizadora y la proximidad de los nuevos encuentros que se generan.

Otro aspecto que atraviesa los tres recorridos analizados es el repertorio de motivos puestos en juego. Por un lado observamos las marcas de los ciclos de la vida, lugares comunes del relato biográfico, por otro, el efecto del fragmento biográfico, la proliferación de un mosaico de objetos, usos y saberes particulares. En este sentido, podemos tomar las distinciones de Régine Robin (2005, p. 50). El autor recuerda el par de términos barthesianos del studium y el punctum, el primero remitiría a la bioses, a los itinerarios típicos de los ciclos vitales, los períodos estructurantes de las biografías. Ellos articulan la sucesión de los legados ligándolos al carácter biológico de la vida cotidiana organizando las secciones que unen los puntos del naci- 
miento y la muerte. En las performances e instalaciones que describimos encontramos numerosas marcas de estos ciclos que segmentan el relato de la vida de una manera coincidente en los tres artistas: huellas que dan cuentan de nacimientos, herencias familiares, ritos de la infancia, recuerdos de la escolarización, las primeras relaciones amorosas, las parejas, las emigraciones y mudanzas, la experiencia de los oficios y las profesiones, la vejez y la clausura de la muerte.

Contrapuesta al lugar común de los ciclos encontramos la idea de biografema, otra noción barthesiana que Robin hace coincidir con el punctum. Este puede definirse como un acento singular que interpela a la afección, no es del orden clasificatorio de las periodizaciones, pone en juego cierta sorpresa, un efecto de exceso, se presenta como un elemento contingente y accidental. Esta operación se encuentra en las estrategias de museificación del yo donde reina la acumulación de objetos, rastros y huellas, Robin consigna esta manera de hacer en la obra de Christian Boltanski al disponer en sus obras de inventarios, archivos y vitrinas con el utópico objetivo de conservarlo todo, en este sentido retoma sus palabras:

[...] decidí consagrarme al proyecto que me interesa hace mucho: conservarse por entero, guardar una huella de todos los instantes de nuestra vida, de todos los objetos que nos rodearon, de todo lo que dijimos y se dijo alrededor de nosotros, he aquí mi objetivo (Robin, 2005, p. 51).

En los tres recorridos propuestos encontramos ambos elementos dispuestos en distintas proporciones. En el caso de Ana, el lugar común de las periodizaciones quizá ocupa un lugar más importante, ya que la formulación de estos tópicos le permite exponer enunciados que más fácilmente convocan a procesos de conversación abiertos. Aún así, el biografema está presente en la elección de ciertos objetos singulares y en el detenimiento del dibujo sobre sus particulares contornos. El análisis intertextual de Gabriel también segmenta estos lugares comunes haciendo hincapié en las divisiones generacionales que se ponen en escena en varias de sus obras, a pesar de trabajar con la lógica de la huella y la impronta. En el caso de ambos, el acento en el bioses permite que la experiencia singular sea más fácilmente proyectada sobre las imágenes de los otros, convocando la fijeza de lugares comunes, espacios estereotipados que evocan las narrativas de un todos. En el otro polo, podemos encontrar las lógicas del trabajo de Verónica donde el relato de las generaciones se encuentra más oculto y la superficie más visible es la del mosaico de fragmentos 
museificados. Aquí, la línea de las generaciones es más subterránea y la claridad de las temporalidades generacionales más desdibujada en capas superpuestas.

El último apunte que esbozaremos corresponde a la naturaleza de las colaboraciones presente especialmente en los proyectos de Verónica y Ana. Como señalamos en ambas propuestas el intercambio está lejos de apoyarse únicamente en una comunicación contextualizada, en un cara a cara paradigmáticamente oral, que las poéticas de la proximidad han privilegiado (Bourriaud, 2008; Kester, 2005; Laddaga, 2006). En los desarrollos de las dos artistas hay un hincapié en los procesos contemplativos, en cierto retraimiento estético introspectivo, aún más pronunciado en la producción de Verónica. En el caso de Gabriel, se focaliza en el hacer, en una aisthesis prekantiana que resiente la distancia para privilegiar la percepción y la sensación - en este sentido pueden leerse sus referencias a la cocina, a la degustación y también a los oficios artesanales - sin excluir, desde luego, el carácter reflexivo e inventivo de estas operaciones, pero sí produciendo acontecimientos más alejados de la contemplación de la mirada.

En los proyectos colaborativos de Ana y Verónica se puede pensar en momentos alternados entre el contacto comunicacional y el retraimiento, en instancias que combinan el estar-juntos con en el apartamiento solitario. En este sentido, recurrir a otra figura barthesiana, la noción de idiorritmia (Barthes, 2003), que anacrónicamente se rescata de diversos preceptos monacales tardoantiguos y medievales. Allí se caracteriza un modo de vida que combina la congregación y simultáneamente las divergencias de los diversos rythmós personales, "donde cada uno vive literalmente su ritmo" (2003, p. 49). El espacio utópico de la idiorritmia se presenta como un lugar intersticial entre los dos modos contrapuestos de la monasticidad: el modelo cenobítico (coenobium, convento) marcado por la estabilidad, la disciplina y la obediencia al superior en la convivencia colectiva; y la anacoresis (anachorein, retiro), el apartamiento solitario marcado por la "rarefacción de los contacto con el mundo" (2003, p. 70). El planteo barthesiano que reivindica la utopías cotidianas de la convivencia problematiza los planteos de la estética relacional. 


\section{Notas}

${ }^{1}$ Entrevista realizada a la artista el 17 de noviembre de 2010 en Buenos Aires, al menos que se indique lo contrario el resto de las citas provienen de esta conversación.

${ }^{2}$ Por esos años Verónica Gómez realizaba un curso sobre técnicas de estudio de bienes culturales en la Comisión Nacional de Energía Atómica. Teniendo como guía sus apuntes implementó diversos procedimientos como la arqueometría, una técnica de medición que permite reconstruir objetos y espacios antiguos.

${ }^{3}$ En la entrevista Verónica reflexiona: “[...] a mí me parece, también lo noto en otros trabajos que fui haciendo y que estoy haciendo ahora también, que siempre hay algo ficcional y de construcción en los escenarios de una casa. Uno elige determinados almohadones con más o menos consciencia pero uno elige rodearse de ciertos objetos y hay algo de esos objetos, en la manera de ubicarlos, en las relaciones que se crean entre sí y con uno, que es un poco teatral. Si se quiere no deja de ser una escenografía útil, donde uno vive y la utiliza, así vos entrás a la casa de alguien y hay como una especie de situación ficcional”.

${ }^{4}$ Este aspecto fue indicado por Pablo Accinelli y Leandro Tartaglia quienes subrayan la emergencia de un sujeto "orientado por la pulsión de una mirada retroactiva y afectado por un humor en particular: la melancolía” (2011, p. 22).

${ }^{5}$ En el diario de observaciones también puede leerse: "Hace cinco años hablé con Caro sobre el origen de la tristeza (de alguna manera las dos siempre estamos tristes). Tengo que volver a ubicarla para decirle que tal vez la mía (el origen) está en España. Raro que pueda existir un lugar físico-geográfico para esas cosas. Es probable que deba viajar a España en algún momento". Fecha: 05 de febrero de 2004.

${ }^{6}$ En el 2005 esta performance se realizo en la Semana de la cultura Brukman. Brukman es una fábrica textil ubicada en la ciudad de Buenos Aires que quedó bajo el control de sus propios trabajadores luego de las crisis del 2001. En esa ocasión se estaba esperando un fallo judicial que podía restituir su propiedad a sus antiguos empresarios. Al respecto el artista señalaba: "Se convirtió en un puestito de información de la situación, entonces se daban conversaciones intensas, había discusiones políticas y todo eso quedaba registrado por un hilo que metaforiza el tejido social. Era algo imposible de enunciar a través del lenguaje verbal, oral o escrito, y sí con la potencia que creo que tienen las artes visuales”. Entrevista desarrollada el 18 de diciembre de 2010, Buenos Aires, salvo que se indique lo contrario, la cita a entrevistas al artista corresponde a esta ocasión.

${ }^{7}$ Esto fue observado por Daniel Quiles, "El objetivo no era alimentar a la audiencia sino resaltar que la receta constituye la transmisión imperfecta de un texto", extractado de "Teorías conspirativas: Notas sobre la Colaboración" en Arte al día internacional, n. 122, Buenos Aires.

${ }^{8}$ Declaraciones extractadas del sitio web: <http://boladenieve.org.ar/>.

${ }^{9}$ En este sentido compartimos lo señalado por Valeria González, "Sin duda, la obra de Gabriel Baggio implica el reconocimiento de un mapa histórico preciso. Desde la perspectiva de género y la validación de las labores domésticas hasta la exploración y rescate del sabor y el olfato en la evolución del arte de acción" (2010, p. 56). 
${ }^{10}$ Declaraciones extractadas del sitio web: <http://boladenieve.org.ar/>.

${ }^{11}$ En este sentido Valeria González expresa "El living es la sala de recibir visitas, la que da a la calle, el lugar donde el decoro es importante, donde una familia exhibe su imagen de sí misma para otros" (2010, p. 55).

${ }^{12} \mathrm{Al}$ respecto la crítica Catherine Nadon (Nadon, Blouine, 2005) apunta: “[...] el desmolde recuerda el contacto del niño con la madre. Como la madre, matriz del niño, los moldes hacen emerger a los platos, encontrando forma a través del mismo contacto".

${ }^{13}$ Esta declaración procede de una entrevista realizada el 11 de marzo de 2011 en Buenos Aires, a menos que se señale lo contrario la referencia a entrevistas tiene la misma procedencia.

\section{Referencias}

ARFUCH, Leonor. El Espacio Biográfico: dilemas de la subjetividad contemporánea. Buenos Aires: Fondo de Cultura Económica, 2010.

BAJTÍN, Mijaíl. Estética de la Creación Verbal. Buenos Aires: Siglo XXI, 2005.

BATHES, Roland. Cómo Vivir Juntos: simulaciones novelescas de algunos espacios cotidianos. Madrid: Siglo XXI, 2003.

BOURRIAUD, Nicolas. Estetica Relacional. Buenos Aires: Adriana Hidalgo, 2008.

BUSZEK, Maria Elena. Extra/Ordinary: craft and contemporary art. Durham: Duke University, 2011.

CALABRESE, Omar. La Era Neobarroca: Madrid: Cátedra, 1999.

DEBORD, Guy. La Sociedad del Espectáculo. Buenos Aires: La Marca, 2008.

DEBORD, Guy. Comentarios sobre la Sociedad del Espectáculo. Barcelona: Anagrama, 2003.

DE CERTEAU, Michael. La Invención de lo Cotidiano 1: artes de hacer, México: ITESO/UIA, 2006.

GALLARDO, Ana. Ana Gallardo Obras 1999-2009. Buenos Aires: Alberto Sendrós, 2010.

GENETTE, Gérard. Palimpsestos: la literatura en segundo grado. Madrid: Taurus, 1989.

GINZBURG, Carlo. Mitos, Emblemas, Indicios: morfologia e historia. Barcelona: Gedisa, 2000.

GOFfMAN, Erving. La Presentación de la Persona en la Vida Cotidiana. Buenos Aires: Amorrortu, 1981.

GONZÁLEZ, Valeria. En Busca del Sentido Perdidio: 10 proyectos de arte argentino. Buenos Aires: Apers, 2010.

HELLER, Ágnes. Sociología de la Vida Cotidiana. Barcelona: Península, 1998. 
IGLESIAS, Claudio. Salud Pública y Cultura Popular: sobre Ana Gallardo y su escuela de baile. Buenos Aires: Galería Alberto Sendrós, 2010.

IGLESIAS, Claudio. Investigación/Infraestructura. Buenos Aires: CCEBA, 2009.

KESTER, Grant. Conversation Pieces: community and Communication in Modern Arte. Los Angeles: University of California Press, 2004.

LADDAGA, Reinaldo. Estética de la Emergencia. Buenos Aires: Adriana Hidalgo, 2006.

NADON, Catherin; BLOUINE, Marcel. Orange, como como? Orange: Centre d'exposition de Sainth-Hyacinthe, 2005.

PARRET, Herman. De la Semiótica a la Estética: enunciación, sensación, pasiones. Buenos Aires: Edicial, 1995.

QUILES, Daniel. Teorías Conspirativas: Notas sobre la Colaboración. Arte al Día Internacional, Buenos Aires, n. 122, p. 67-78, feb./mar. 2008.

ROBIN, Régine. La autoficción. El sujeto siempre en falta. In: ARFUCH, Leonor. Identidades, Sujetos y Subjetividades. Buenos Aires: Prometeo, 2005. P. 43-56.

SIBILIA, Paula. La Intimidad como Espectáculo. Buenos Aires: Fondo de Cultura Económica, 2008.

TRASTOY, Beatriz. Teatro Autobiográfico: los unipersonales de los 80 y 90 en la escena argentina. Buenos Aires: Nueva Generación, 2002.

Federico Baeza es licenciado en Artes por la Universidad de Buenos Aires (UBA), doctorando en la misma casa de estudios. Ha obtenido becas doctorales otorgadas por dicha universidad y por el Consejo Nacional de Investigación en Ciencia y Técnica (CONICET). Es profesor de grado y posgrado en la carrera de Crítica de Arte en el Instituto Universitario Nacional del Arte (IUNA).

E-mail: fed.baeza@gmail.com 